症 例

粘液分泌が多量にみられた CA19-9 産生胃粘液癌の 1 例 山梨赤十字病院 ${ }^{1)}$, 昭和大学第 2 外科 ${ }^{2)}$

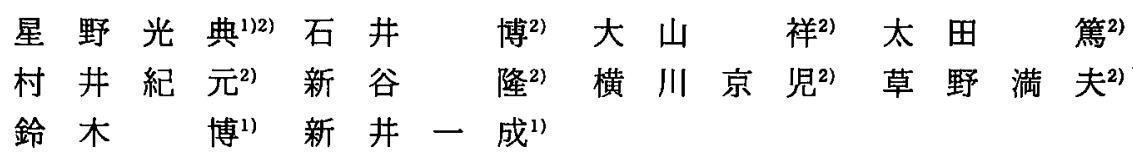

CA19-9 産生胃粘液癌の 1 例を経験したので報告する.症例は 46歳, 男性. 検診で CA19 -9 高値を指摘され, 精查により, 胃幽門前庭部の 1 型進行胃癌と診断された. 1996年 7 月12日幽門側胃切除, リンパ節郭清術を施行し, 病理所見では癌部の本体は粘液結節か らなり，免疫組織学的にも抗 CA19-9 抗体に染色され CA19-9 産生胃癌と診断された. 血清 CA19-9 は胃切除と共に急速に低下し，3 年経過した現在に至るまで正常値である が, CA19-9 高值群は予後不良であるため今後も厳重な経過観察が必要であるものと考 えられた。

CA19-9 産生胃癌の本邦報告例は，9例しかなくまたCA19-9 産生胃粘液癌は自験例 も含め 2 例とまれな症例と考えられたため報告した。

索引用語：CA19-9 産生胃癌, 胃癌, 粘液癌

\section{緒言}

今回，われわれは Carbohydrate Antigen 19-9（以 下CA19-9）産生胃癌の 1 例を経験した。CA19-9は

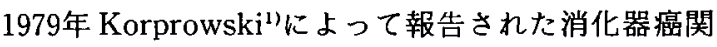
連抗原であり，とくに膵癌および胆道癌に特異性が高 いとされているが，胃癌や大腸癌でも高值を示すこと は周知であり,CEA と共に最も汎用されている腫崵マ 一カーの一つである。われわれが検索した限りでは冲 永ら が定義したCA19-9 産生腫瘍に合致する報告例 は少ないが, 今回われわれは, 胃癌のなかでも頻度が まれな胃粘液癌で, かつ, CA19-9 産生胃癌と診断しえ た症例を経験したので報告する。

$$
\text { 症例 }
$$

症例：46歳, 男性.

主訴：CA19-9 高值.

家族歴：特記すべきことなし。

既往歴：特記すべきことなし.

現病歴：1996年 5 月，健診で血清 CA19-9 の高值を 指摘され当院外来を受診し，血液検査で血清 CA19-9 が129.4U $/ \mathrm{ml}$ と異常高値を示したため，6月精查のた め入院とした。
入院時現症：体格中等度，栄養状態は良好。眼球・ 眼瞼結膜に實血および黄疸を認めず, 腹部は平坦かつ 軟で圧痛はなく，肝脾は触知しなかった．表在リンパ 節は触知せず，その他に異常所見を認めなかった。

入院時検査所見 : 血算, 血液生化学検査に異常所見 を認めなかった。腫湯マーカーでは血中 AFP, CEA は 正常範囲であったが, 血中 CA19-9 值は450U/mi と異 常高值を示していた（表 1 )。

上部消化管造影検查：胃前庭部後壁に表面平滑な辺 縁平滑で半円球状の隆起性病変が認められた（図 1 ).

\section{表 1 入院時血液検查結果}

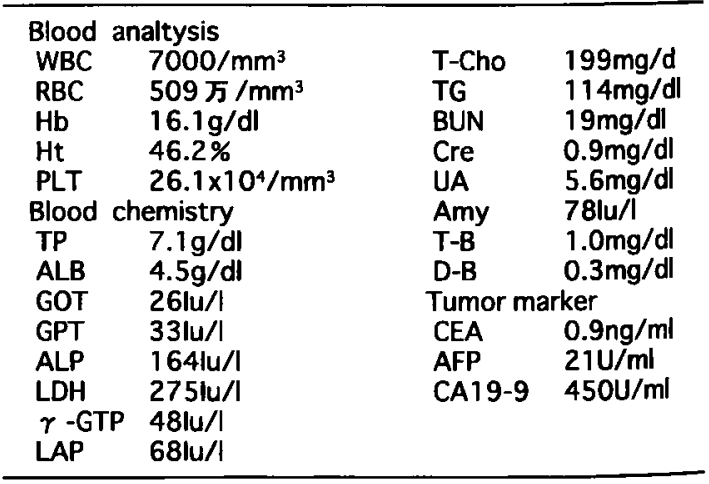

1999年 9 月 3 日受付 2000 年 1 月 12 日採用 


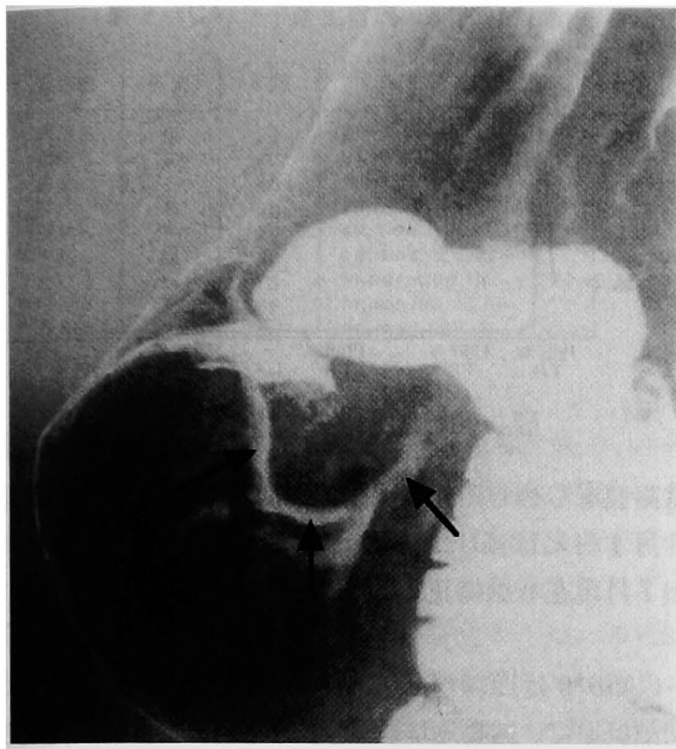

图 1 上部消化管検査：胃前庭部に隆起性病変が認めら れた (矢印)。

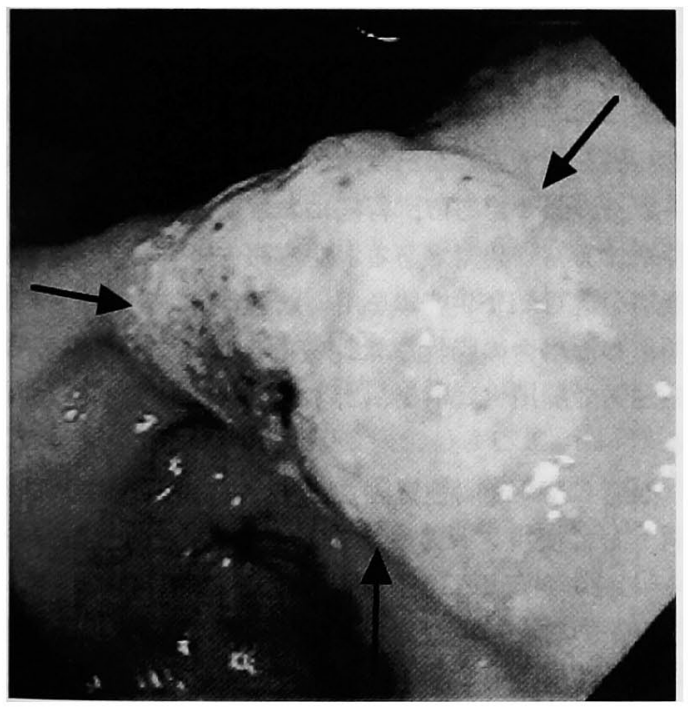

图 2 上部消化管内視鏡検査：䓢前庭部小弯後壁より に黄白色の粘液が付着した隆起性病変が認められた (矢印)

上部消化管内視鏡検查：胃前庭部小弯後壁よりに立 ち上がりの急峻で表面に黄白色の粘液が付着した隆起 性病変が認められ，生検で Group V，低分化型腺癌の 診断が得られた（図 2 )。

腹部 CT：胃前庭部後壁に限局性の壁の肥厚が認め られたが，明らかなリンパ節腫大はみられず，また，

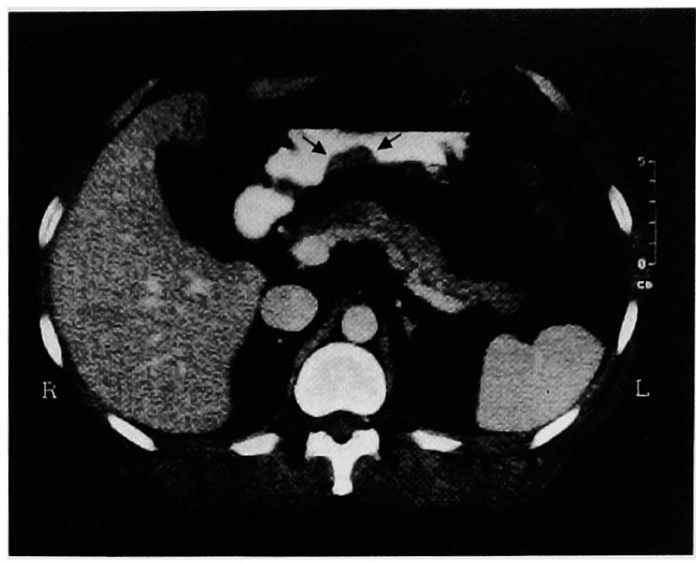

図 3 腹部 CT：胃前庭部後壁に限局性の壁の肥厚が認 められた (矢印).

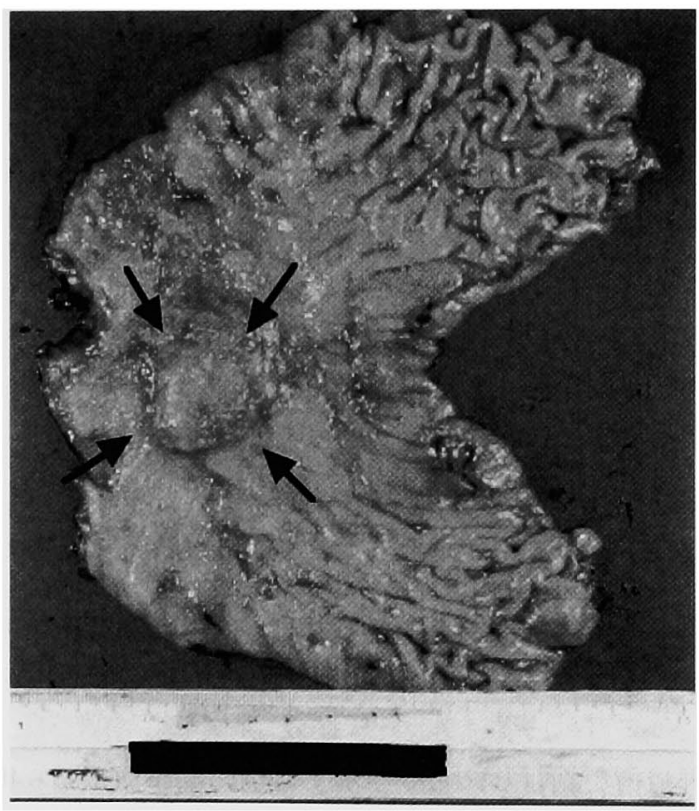

図 4 切除標本：胃幽門小弯に $35 \times 40 \mathrm{~mm}$ の 1 型の病変 を認めた (矢印).

その他の臓器に異常は認められなかった（図 3 ).

腹部超音波検查, 胸部 CT, 注腸検查を施行したが, 異常は認められなかった。以上から，1 型胃癌と診断 し，1996年7月12日手術を施行した。

手術および切除標本肉眼所見：全麻下に開腹したと ころ，胃前庭部小弯後壁に腫湯があり，触診上，槳膜 下浸潤が疑われた，腫湐と膵との癒着や肝転移および 腹水はなく，術中超音波検査を施行したが，膵㵴に異 常は認められなかった. 幽門側胃切除術, D2 リンパ節 


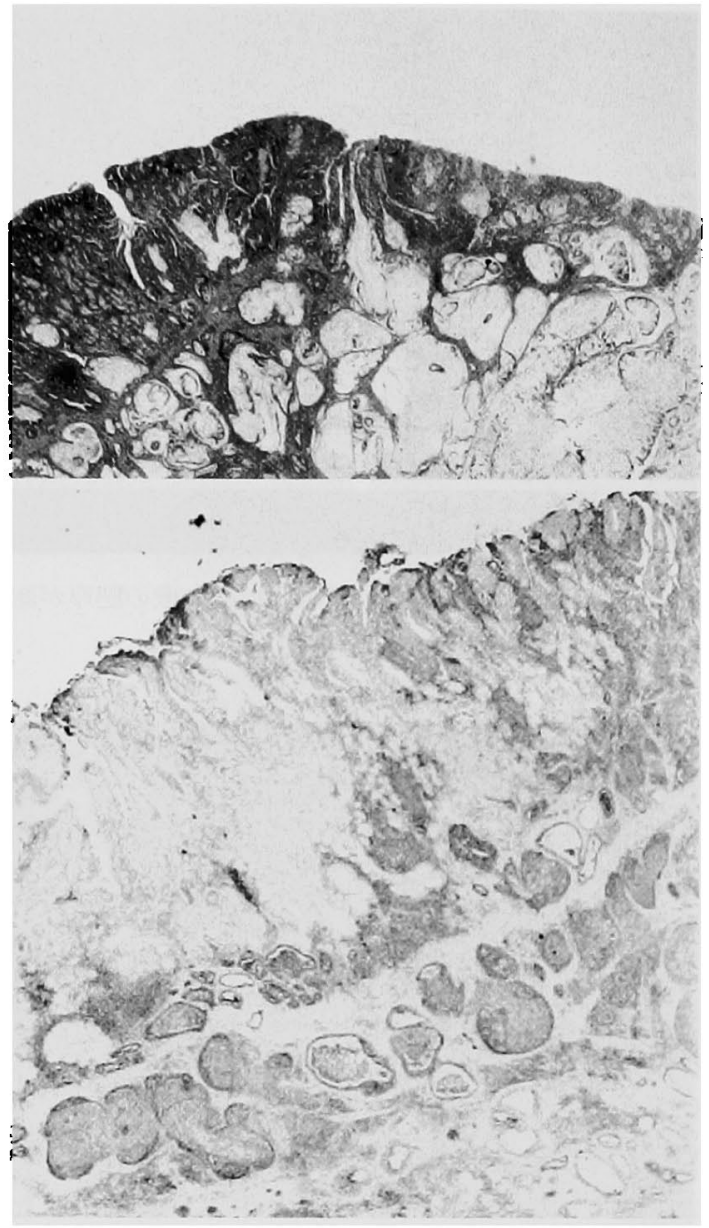

図 $5 \mathrm{a}$ 病理組織学的所見：腫場は粘液癌で，媣達度は seにまで達していた。

b 免疫組織学的染色：癌細胞の細胞質と管空内の 粘液にCA19-9 の陽性所見が認められた。

郭清術を施行し，切除標本では幽門部小弯に $35 \times 40$ $\mathrm{mm}$ の 1 型の腫場が認められた（図 4).

病理組織学的所見：癌部の主体は粘液結節からな り, 粘液内には異型の強い癌細胞が認められ，また， 印環細胞が浮遊している所見もみられた（図 $5 \mathbf{a}$ ). 進 行度は, pT3, pN1, sH0, sP0, sCY0, fStageIIIA ${ }^{2)}$ であった。

免疫組織学的所見：抗 CA19-9 モノクロナール抗体 （セントコア社製）を用いた酵素抗体法による免没染 色では，粘液結節と異型腺管を構成する癌細胞の細胞 質および管空内の粘液に陽性所見が認められた（図 5 b).

CA19-9 の推移：入院時, CA19-9は450U $/ \mathrm{ml}$ と異

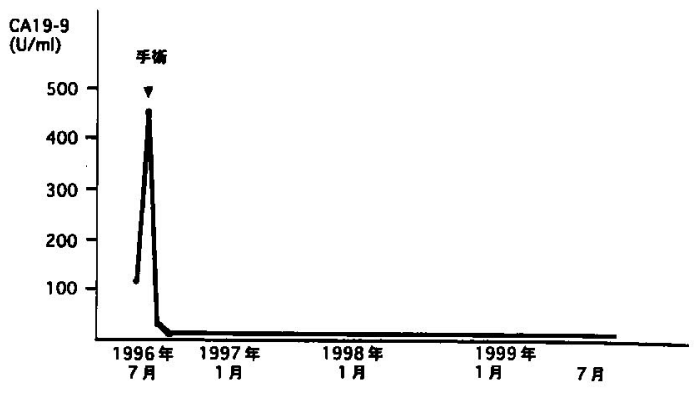

図 6 血清 CA19-9 の経時的推移

常高值をしめしたが, 術後第三病日で $36.9 \mathrm{U} / \mathrm{ml}$, 同年 8 月 1 日には $15 \mathrm{U} / \mathrm{ml}, 9$ 月には $3.7 \mathrm{U} / \mathrm{ml}$ 以下で1999 年 7 月現在も維持正常である（図6).

\section{考 察}

CA19-9 は1979年 Koprowski ${ }^{11}$ よって報告された 糖鎖抗原で，結腸癌培養細胞 SW1116によって兔疫さ れたマウス脾細胞のハイブリドーマから選ばれたモ， クロナール抗体により認識された抗原である。またこ の抗原の决定基は細胞膜由来の monoganglioside て, Lewis 血液抗原 $\mathrm{Le}^{\mathrm{a}}$ の糖鎖抗原にシアル酸がついた構 造をもっている.CA19-9 は消化器癌の中でも膵臟, 胆 道癌に特異性が高いとされているが，胃癌や大腸癌で も高値を示すことがあり，最もよく利用される腫瘍、 一カーの一つである. 胃癌における血清の CA19-9陽 性率は30\%～40\%であるとする報告144 -6)が多い. 組織 標本を抗 CA19-9 抗体を用いた醉素抗体法により特殊 染色した場合の陽性率は比較的高率であり多淵ら”は $62.3 \%$ で関川は需は $54.5 \%$ に陽性であったと報告してい る.

血清 CA19-9 陽性胃癌と CA19-9 産生胃癌とが同義 語として使用されることは珍しくない。そこで冲永 $ら^{3}$ は 1 ）血清 CA19-9 が高值である 2) 胃癌組織内に CA19-9 の存在が確認される 3 ) 胃癌組織の切除によ って血夜中の CA19-9 の低下が確認されるという3 点 を満たすものをCA19-9 産生胃癌と定義した。自駼例 は冲永らの定義を満たしており CA19-9 産生胃癌と診 断してよいと思われる.本邦において,血清 CA19-9 陽 性で免疫組織学的にもCA19-9 が証明された胃癌報告 例は自験例を含めて，いまだ 9 例91 16)のみである（表 2). 9 例中, 男性 5 例, 女性 4 例. 年龄は 43 歳 $~ 80$ 歳. 9 例のうち 6 例は進行癌で, 3 例が早期癌で診断され た. 組織型は 4 例が中分化型腺癌で低分化型腺癌 2 例, 印環細胞癌 1 例，粘液癌 2 例である. 粘液癌は 2 例の みで，ましてや粘液癌の本邦における出現頻度が全胃 
表 2 CA19-9産生胃澏 本邦報告例

\begin{tabular}{|c|c|c|c|}
\hline 劸告者 & 性別 & 年幽 & \\
\hline 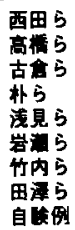 & $\begin{array}{l}\mathbf{M} \\
\mathbf{F} \\
\mathbf{F} \\
\mathbf{F} \\
\mathbf{M} \\
\mathbf{M} \\
\mathbf{M} \\
\mathbf{M}\end{array}$ & $\begin{array}{l}51 \\
60 \\
43 \\
58 \\
71 \\
80 \\
75 \\
62 \\
46\end{array}$ & $\begin{array}{l}\text { pm,sig,INF } v, I y 1, v 0 \\
\text { ss,mod, } ₹ \sigma \text { 他不明 } \\
\text { mod, } ₹ \sigma \text { 他不朋 } \\
\text { sm,mod,INF } \beta, I y 0, v 0, n 0 \\
\text { ss,mod,Iy1,v0,n1 } \\
\text { se,muc, } ₹ \sigma \text { 他不明 } \\
\text { m,por,mod,INF } \gamma, I y 0, v 0, n 0 \\
\text { m,Dor,Iy0,v0,no } \\
\text { se,muc,INF } \beta, \mid l v 1, v 1, n 1\end{array}$ \\
\hline
\end{tabular}

癌のうちで $4.15 \%(302 / 7283)^{17) ~ 19)}$ と低率であり, 冲永 らの定義に該当する CA19-9 産生胃粘液癌の報告はき わめてまれである．癌で産生されたCA19-9 の末梢血 への移行には何らかの機序が存在すると考えられてい る.近ら ${ }^{20)}$ にると, 産生細胞が直接血中へはいる可能 性が高いとし，多淵ら゙はリンパ管侵襲により経りン

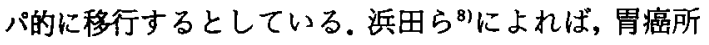
属リンパ節への転移が進展するにつれて血清 CA19-9 の平均は上昇傾向を認めるも有意差はなく, CA19-9 高値がリンパ節転移を反映するとは言い切れないとし ている.川本ら ${ }^{21)}$ は, 紐胞の癌化による合成酵素異常で CA19-9 が細胞内に蓄積され, さらに癌細胞が発育・浸 㵎していく過程で CA19-9 の産生能や分泌能は変化す ると報告している。CA19-9て染色される癌細胞の部 位は, 検索した限りでは印環細胞癌, 中分化型腺癌で は細胞質であるが，本例の様な粘液癌の場合は粘液結 節が染色された。自験例では，抗 CA19-9 て腫湟の大 部分を占める粘液結節が染色されたことと上部消化管 内視鏡検查で腫瘍の表面に大量に粘液が付着していた ことを考慮すると細川ら ${ }^{22)}$ の報告のように, CA19-9 が大量に癌細胞で産生され，末梢血に流出し血清 CA19-9 が異常高值を示したものと考えられた。

自験例は, fStageIIIA であり，また, CA19-9 $\mathrm{ml}$ の高值群は, 予後が不良であるとの報告もみられ ${ }^{23)}$ 現在 CA19-9 值は正常值であるが, 今後厳重なる経過 観察が必要と思われた。

\section{結 語}

血清 CA19-9 高值を示した胃粘液癌に対し免疫組織 学的検討を加え CA19-9 産生胃粘液癌と診断しえた 1 例を経験したので若干の文献的考察を加え報告した。

\section{文 献}

1) Koprowski H, Steplewski $Z$, Mitchell $K$, etal : Colorectal carcinoma antigens detected by hybridoma antibodies. Somatic Cell Genet 5 : 957-972, 1979
2）胃癌研究会編：胃癌取扱い䙺約, 改訂第 13 版, 金 原出版, 東京, 1999

3）冲永功太, 横畠徳行, 治部達夫 : CA19-9 産生置 瘦. 別冊日本臨床, 領域別症候群シリース 5 , 消 化管症候群 (上巻), 日本臨床社, 大阪 1994, p238 $-240$

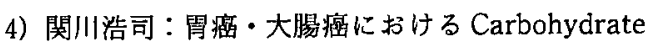
antigen 19-9 の臨床的桧討. 日消外会誌 $19: 734$ $-740,1986$

5) 石田正夫, 暒田芳弘, 中嶋良行：新しい腫湐関連 抗原 CA19-9 测定の臨床的意義. 基礎と臨 17 ： $371-378,1983$

6）浜副隆一, 古賀成昌, 前田迪郎 : 胃癌患者血清中 $の$ tissue polypeptide antigen $と$ carbohydrate antigen の臨床的評価. 日消外会誌 $20: 29-33$, 1987

7）多淵芳樹, 山口浩之, 斉藤洋一：胃癌における腫 瘍関連抗原 CEA と CA19-9 の末梢血中移行機序 に関する臨床病理学的・免疫組織学的研究. 日外 会誌 $89 ： 1181-1191 ， 1988$

8）浜田芳則, 駒田尚直, 今林伸康他：胃癌患者にお ける carbohydrate antigen 19-9 の臨床的意義. 日消外会誌 $19: 909-913 ， 1986$

9）西田康一，吉川敏一，垣見依子他：免疫組織学的 検討を行った CA19-9 産生胃癌の一例。外科診療 $4: 513-516,1985$

10）高橋 豊, 磨伊正義, 荻野知巳他：Alpha-phetoprotein, carcinoembryonic antigen, carbohydrate antigen 19-9 産生胃癌の一例一免疫組織 学的検討一. 日消外会誌 $19: 2421-2423,1986$

11）古倉 聡, 森田 豊, 上田茂信他：血清 CA19-9 が 異常高值を示し, AFP, CEA, HCG も高值であっ た胃福の 1 例. 日消病会誌 $84: 2456,1987$

12）朴 義男, 粉川隆文, 平山裕一他：CA19-9 高值早 期胃癌の一例. 京府医大誌 $100: 277-282,1991$

13）浅見恵司：CA19-9 産生胃癌の一治験例。東京医 師会誌 $45: 937-943,1992$

14）岩頼 豪, 今井陽一, 大西恭子他：粘膜下腫瘍形 態を呈した CA19-9 産生胃粘液癌の 1 例. 日消病 会誌 $94: 746-750,1997$

15）竹内邦夫, 都築 靖, 安藤 哲他：血清 CA19-9 が 高值を示した胃粘膜内癌の 1 例. 日臨外会誌 $59: 990-993,1998$

16）田濢賢一，黒田吉隆，木村寛伸他：術前血中 CA19 
-9 が高值を示した早期胃癌の 1 例. 日臨外会誌 $59: 994-998,1998$

17）山際裕史：鼠腹管の膠様瘦 (collid carcinoma). 臨病理 $33: 924-928,1985$

18）佐々英達，嘉納 尊：胃粘液癌と大腸粘液湛との 比較研究. 日消病会誌 $76: 659-667,1979$

19）竹下公矢, 神户文雄, 丸山道生 他：胃膠様腺癌の 臨床病理学的検討.日消外会誌 $19: 1711-1717$, 1986

20）近裕：胃癌におけるCEA, AFP, CA19-9の 血中濃度と免疫染色による産生能との比较検討.
東京医大誌 $46: 555-562,1988$

21）川本 徹, 斉藤 澄, 称 健他 : 抗 proliferating cell nuclear antigen（PCNA）抗体を用いた肝門 部胆管癌の細胞増殖能の研究ーPCNA 発現と CEA, CA19-9, ならびに EGF receptor 発現との 関係一。消病会誌 $90: 144-153,1993$

22）細川治, 山道 昇, 山崎 信他: 早期胃膠様腺 癌の榆討. 癌の瀶 $4: 1081-1088,1986$

23）谷口哲也, 澤田 隆, 清水 哲他：胃癌における 術前 CEA, CA19-9 値と手術予後についての検 討。日臨外医会誌 $58 ： 2499-2504,1997$

\title{
A CASE OF CARBOHYDRATE ANTIGEN 19-9 PRODUCTING GASTRIC MUTINOUS ADENOCARCINOMA WITH TOO MUCH MUCOUS SECRETING
}

\author{
Mitsunori HOSHINO ${ }^{122}$, Hiroshi ISHII ${ }^{2)}$, Sho OYAMA ${ }^{2)}$, Atsushi OHTA $^{2)}$, \\ Noriyuki MURAI', Takashi NIIYA ${ }^{21}$, Kyoji YOKOKAWA ${ }^{2)}$, Mitsuo KUSANO ${ }^{21}$, \\ Hiroshi SUZUKI" and Kazusige ARAI" \\ "Yamanashi Red Cross Hospital \\ ${ }^{2}$ Second Department of Surgery, Showa University
}

We report a rare case of carbohydrate antigen (CA) 19-9 producting mucinous gastric cancer with too much secreting. A 46-year-old man was pointed out high value of serum CA19-9 by a routine health examination. So He was admitted to the hospital in order to rule out malignant disease. He was diagnosed as having advanced gastric cancer at the posterior wall on the antrum by gastrointestinal endoscopy.

Distal gastrectomy with regional lymph node dissection was performed. Microscopic examination revealed that the cancer was arose from mucous nodose and immunohistochemical stain of the resected material was positive for anti-CA19-9 monoclonal antibody was positive. The value of serum CA19-9 increased after admission and remarkaably decreased to the normal range after the gastrectomy. The normalized CA19-9 level has been kept up to nou for 3 years. Patients group with high CA19-9 valeu has a poor prognosis, and hence further strict observation of his clinical course will be nesessary. 